Kalcounis, M.C. and R.M. Brigham. 1995. Intraspecific variation in wing loading affects habitat use by little brown bats (Myotis lucifugus). Canadian Journal of Zoology 73:89-95.

Made available courtesy of National Research Council Canada.

\title{
Intraspecific variation in wing loading affects habitat use by little brown bats (Myotis lucifugus)
}

\author{
Matina C. Kalcounis and R. Mark Brigham
}

Abstract: Morphological constraints have been linked to habitat partitioning by different species of animals. Interspecific differences have been explored, but less is known about the relationship between individuals of the same species. The purpose of this study was to determine if habitat use by little brown bats (Myotis luctfugus) varies with body mass of individuals. From aerodynamic thcory, we predicted that bats with higher body mass will have highcr wing loadings, should be less manoeuvrable, and thus tend to forage in areas where there are fewer obstacles to detect and avoid (clutter). Habitat was ranked into four zones based on the degree of clutter, and habitat use was assessed by measuring the time that males and nonreproductive, pregnant, lactating, postiactating, and artificially loaded females spent in each habitat zone. To test the assumption that a selective advantage accrues to bats foraging in clutter, we measured the availability of flying insects in cluttered and open habitats. Insect trap samples revealed a higher density of insect prey in more cluttered habitats. Body mass was positively correlated with wing loading. Overall, males were smaller than females with respcct to mass and wing loading; however, these differences did not translate into differential habitat use. As predicted, there was a significant relationship between individual wing loading and habitat use, with heavier bats (greater wing loading) foraging in less cluttered areas.

Résumé : Le partage de l'habitat par différentes espèces d'animaux est lié à des contraintes morphologiques. Les différences spécifiques ont fait l'objet d'études, mais les relations entre individus de la même espèce ont été peu explorées. Nous avons essayé de déterminer si la répartition de l'habitat est reliée à la masse corporelle des individus chez le Verspertilion brun, Myotis lucifugus. Nous basant sur les principes de l'aérodynamique, nous avons posé en hypothèse que !es chauves-souris les plus lourdes, dont les ailes portent donc une charge plus élevée, sont moins mobiles et tendent donc à chercher leur nourriture dans des lieux où le nombre d'obstacles à détecter et à éviter est moins élevé. L'habitat a été séparé en quatre zones délimitées d'après leur degré d'encombrement et l'utilisation de l'habitat a été estimée en évaluant la durée de séjour des mâles, des femelles non reproductrices, des femelles enceintes, des femelles nourricièrcs, des femelles après le scvrage et des femelles dont la charge a été augmentée artificiellement. Pour éprouver l'hypothèse selon laquelle il y a, pour les chauves-souris, un avantage évolutif à chercher la nourriture dans les lieux à fort pourcentage d'encombrement, nous avons mesuré l'abondance des insectes en vol dans les endroits encombrés et les endroits ouverts. Les échantillons recueillis dans les pièges à insectes ont révélé que la densité des proies était plus élevée dans les habitats encombrés. La masse corporelle était en corrélation positive avec la charge exercée sur les ailes. Dans l'ensemble, les mâles étaient plus petits que les femelles, aussi bien quant à la masse que quant à la charge sur les ailes, mais ces différences ne se sont pas reflétées dans le choix des habitats. Tel que le supposait l'hypothèse, il y avait une relation significative entre la charge exercée sur les ailes d'un individu et son choix d'un habitat $e t$ les chauves-souris les plus lourdes (done à charge phis grande sur les ailes) cherchaient leur nourriture dans les endroits les moins encombrés.

[Traduit par la Rédaction]

\section{Introduction}

Morphological differences between species can affect how they perform ecologically relevant tasks (Losos 1990). For

I Received March 31, 1994. Accepted October 6, 1994.

M.C. Kaleounis' and R.M.righam. Department of Biology, University of Regina, Regina, SK 545 0A2, Canada. example, certain morphological features may predispose organisms to feed on specific prey types and adopt certain foraging strategies. It should thus be possible to make infer- ences about an animal's ecology and behaviour from its morphology (Grant 1986).

The structure and shape of a flying animal's wing influence flight performance capabilities and place energetic and mechanical limitations on where it can forage (Norberg 1981). Many insectivorous bats pursue actively flying, agile prey in areas where clutter, i.e., the number of obstacles to detect 
and avoid (e.g., tree trunks, branches), is very high. More manoeuvrable species tend to hunt in more cluttered areas (Aldridge 1986a). In British (Aldridge I986b), Australian (McKenzie and Rolfe 1986; Crome and Richards 1988), and African (Aldridge and Rautenbach 1987) bat communities, foraging site selection by a species is correlated with manoeuvrability.

Manoeuvrability refers to the space required by a flying animal to alter its flight path (Aldridge 1987; Norberg and Rayner 1987; Aldridge and Brigham 1988). Wing loading is defined as the weight of a flying animal divided by its total wing area. In aerodynamic terms, it is important because it affects flight speed. An increase in body mass results in an increase in minimum flight speed, which increases the minimum turning radius and thereby decreases manoeuvrability (Pennycuick 1975). Thus, bats with high mass or wing loading turn less tightly and have lower manoeuvrability than bats with lower mass or wing loading (Aldridge 1987).

The interspecific trends of wing loading, manoeuvrability and flight performance lead to the question of whether intraspecific variation in mass results in changes in habitat use. There are many potential sources of Mass variation within a species. Female bats carry foetal and associated masses for relatively long periods of time and may experience increases in body mass of up to $30 \%$ (Kurta and Kunz 1987; Myers 1978; Hughes and Rayner 1993). As well, the body mass of females at the start of lactation may surpass that at the start of pregnancy (Speakman and Racey 1987). To reduce the risk of energy shortages during reproduction, females may store extra fat reserves during early pregnancy (Webb et al. 1992). In species of insectivorous bats that show reverse sexual dimorphism, females may have larger body masses than males (Myers 1978; William and Findley 1979).

The aim of this study was to determine if intraspecific variation in mass, and hence wing loading, results in differences in foraging behaviour and habitat use. We predicted that, as wing loading increases, manoeuvrability should decrease and bats should tend to forage in areas where the number of obstacles is lower. The effects of artificially loading, or adding mass to, bats was also examined. We also tested the assumption that there are higher insect densities within cluttered areas and thus bats gain a selective advantage from foraging there.

We tested our predictions using the little brown bat (Myotis lucifugus); a small insectivorous bat (adult mass 6-11 g; van Zyll de Jong 1985). These bats feed on a variety of flying insects 3-10 mm long (Anthony and Kunz 1977), including members of the orders Diptera, Ephemeroptera, Trichoptera, Lepidoptera, Isoptera, Homoptera, and Coleoptera (Buehler 1976a; Belwooci and Fenton 1976). This species is known to forage over the surface of calm water and within clutter (Fenton and Barclay 1980).

\section{Methods}

\section{Study area}

Fieldwork was conducted in the West Block of Cypress Hills Provincial Park $\left(49^{\circ} 34^{\prime} \mathrm{N}, 109^{\circ} 53 \mathrm{~W}\right)$, approximately $60 \mathrm{~km}$ southwest of Maple Creek, Saskatchewan. Habitat-use data were collected from May to August 1992. Morphological data were collected during the same months in 1991, 1992, and 1993. The vegetation of the area consists of trembling
Fig. 1. Four habitat types used to classify bat foraging behaviour: 1 , open area; 2 , within $1 \mathrm{~m}$ of water surface; 3 , within $1 \mathrm{~m}$ of the edge of trees; 4 , within the branches and foliage of trees.

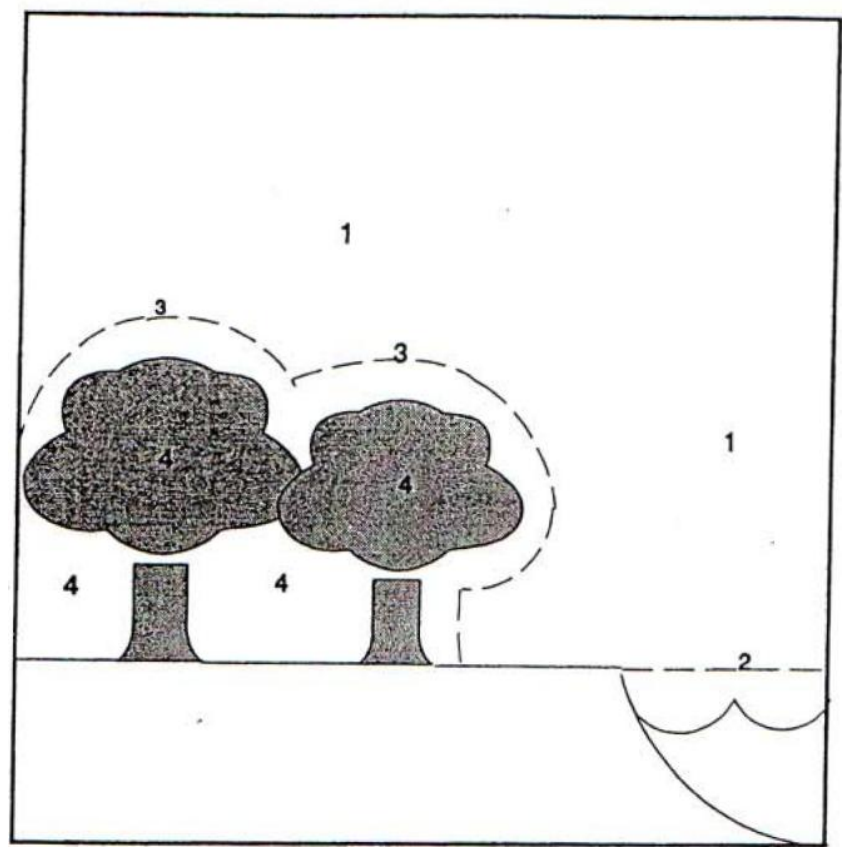

aspen (Populus tremuloides) and white spruce (Picea glauca) forest and fescue prairie. The only water sources are Battle Creek and its tributaries and small ponds created by the activities of beaver (Castor canaclensis).

\section{Insect availability}

To determine if there were more insects in areas with clutter, we used both sticky (Kalcounis et al. 1992) and light-suction (Kunz 1988) traps to collect flying insects in an open grassland field and a white spruce forest. Two types of trap were used so as to sample as wide a variety of insect types as possible and to assess the prey available to M. lucifugus as reliably as possible. One of each type of trap was hung $1 \mathrm{~m}$ above the ground in each sampling area at dusk and insects were collected the following morning at dawn. Insects were identified to order, counted, and measured (length from the head, excluding the antennae, to the tip of the abdomen). Only insects in the orders and size range of prey known to be eaten by M. lucifugus were included in the analysis.

\section{Habitat use}

Individual M. lucifugus were caught in mist nets placed in suspected foraging areas. We sexed the bats and characterized the breeding condition of each female as follows: pregnant, by palpation; lactating, by the expression of milk from a nipple; postlactating, by bare patches around the nipples but no milk expression; or non-reproductive. To increase wing loading, we used surgical adhesive to attach a gelatin capsule filled with approximately $2 \mathrm{~g}$ of modelling clay to the ventral surface of the bat. This class is henceforth referred to as artificially loaded. Juveniles were distinguished from adults by the lack of ossification of the metacarpal-phalangeal joint on the third digit (Racey 1974) and were not included in this study, as the ontogeny of flight makes predictions difficult (Buehler 1980). 
Fig. 2. Mean number of insects caught by the two trap types in open (0) and cluttered (0) habitats.

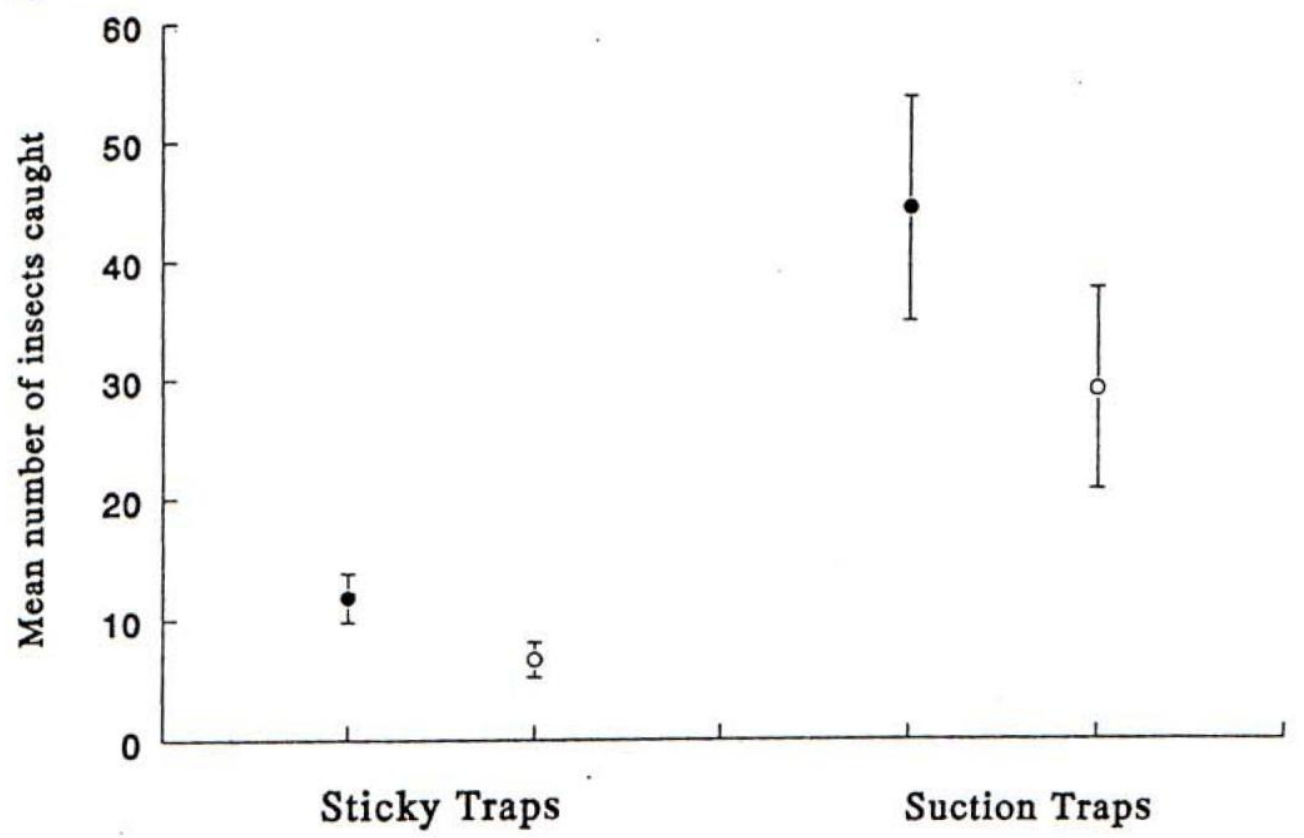

At the site of capture we measured body mass $(M)$ and made a tracing of the right wing onto metric graph paper. Wing area $(S)$ was measured by counting the squares enclosed by the trace, following the convention of Norberg and Rayner (1987), where the flight surface comprised the area of both wings, the area of the entire tail membrane, and the body area between the wings, excluding the head. Wing loading (Qs) was calculated using the following equation:

$$
Q_{\mathrm{s}}=(M \cdot \mathrm{g}) / S
$$

where $M$ is mass $(\mathrm{g})$ of the individual, $g$ is acceleration $\left(\mathrm{m} / \mathrm{s}^{2}\right)$ due to gravity, and $S$ is wing area $\left(\mathrm{m}^{2}\right)$.

Habitat use by bats of a particular class (male, nonreproductive, pregnant, lactating, postlactating, artificially loaded female) was assessed by observing the flight of lighttagged foraging individuals (Buehler 19766; Barclay and Bell 1988; Aldridge and Rautenbach 1987; Brigham et al. 1992; Saunders and Barclay 1992). Light tags consisted of gelatin capsules filled with chemiluminescent liquid (Cyalume; American Cyanamid Company, Milton, Fla.). We affixed a tag to the bat's ventral surface using surgical adhesive and released light-tagged individuals at the site of capture. Light tags weighed less than $0.5 \%$ of the bat's body mass and did not appear to hinder flight (Aldridge and Brigham 1988). They are groomed off within a few days (Barclay and Bell 1988). Light-tagging was not undertaken on nights with rain, heavy wind, or ambient temperatures below $0^{\circ} \mathrm{C}$ :

Light-tagged bats were followed until they flew out of sight. Their location and foraging activities were continuously spoken into microcassette recorders and later transcribed to determine the amount of time(s) that bats. spent in each habitat type. It was possible to tell if the bats were feeding because this species normally emits echolocation calls at rates of 10-20/s. However, when potential prey are encountered, the rate rises to as many as 250 calls/s (Griffin et al. 1965). Ultrasonic mini-bat detectors (Ultra Sound Advice, 23 Aberdeen Road, London N5 2UG, U.K.) render these echolocation calls audible to humans and were used to ensure that the bats were foraging in, and not simply flying through, the habitats (Fenton 1988).

Potential foraging habitats were divided into four types ranked subjectively according to the degree of clutter and the dominant substrate type (see Brigham et al. 1992). The habitats were assigned values of $1-4$, with 4 being the most cluttered (Fig. 1).

The time spent by each light-tagged individual in each habitat was used to calculate a habitat use (HU) index based on

$$
\mathrm{HU}=\Sigma\left(H \cdot t_{h} / t\right)
$$

where $H$ is rank of the habitat, th is time spent in habitat of rank $H$, and $\mathrm{t}$ is total time for which the bat was observed (Aldridge and Rautenbach 1987). HU values reflect the average complexity of habitat use, with higher values indicating proportionally more time spent in cluttered areas.

Statistical analysis

A two-tailed paired $t$ test (Zar 1984) was used to compare the numbers of insects collected in open and cluttered sites. Parametric one-way analysis of variance was used to assess morphometric differences between sexes and classes. Where differences were significant, multiple comparisons were made using Tukey's test (Zar 1984). To test for relationships between mass and wing loading and wing loading and habitat use, we used Model I least squares regression analysis. Since HU represents a proportion, a nonparametric Kruskal - Wallis test was used (Zar 1984). Data are presented as means + $1 \mathrm{SE}$ and a 0.05 rejection criterion was employed for all tests.

\section{Results}

We caught and light-tagged 34 adult female and 13 adult male M. lucifitgus. We light-tagged on 19 nights and generated a total of $4691 \mathrm{~s}$ (78.2 $\mathrm{min})$ of habitat-use data. On 5 nights we were able to light-tag females of more than one class. All artificially loaded bats were female. For overall 
Fig. 3. Relationship between body mass and wing loading when individuals from all classes are included $(\mathrm{O}$, regression line shown): $y=0.93+0.77 x ; r^{2}=0.69, F_{[1.45]}=98.2$. Excluding the artificially loaded individuals $(\bullet): y=1.38+$ $0.70 x ; r^{2}=0.59, F_{[1.41]}=59.70$.

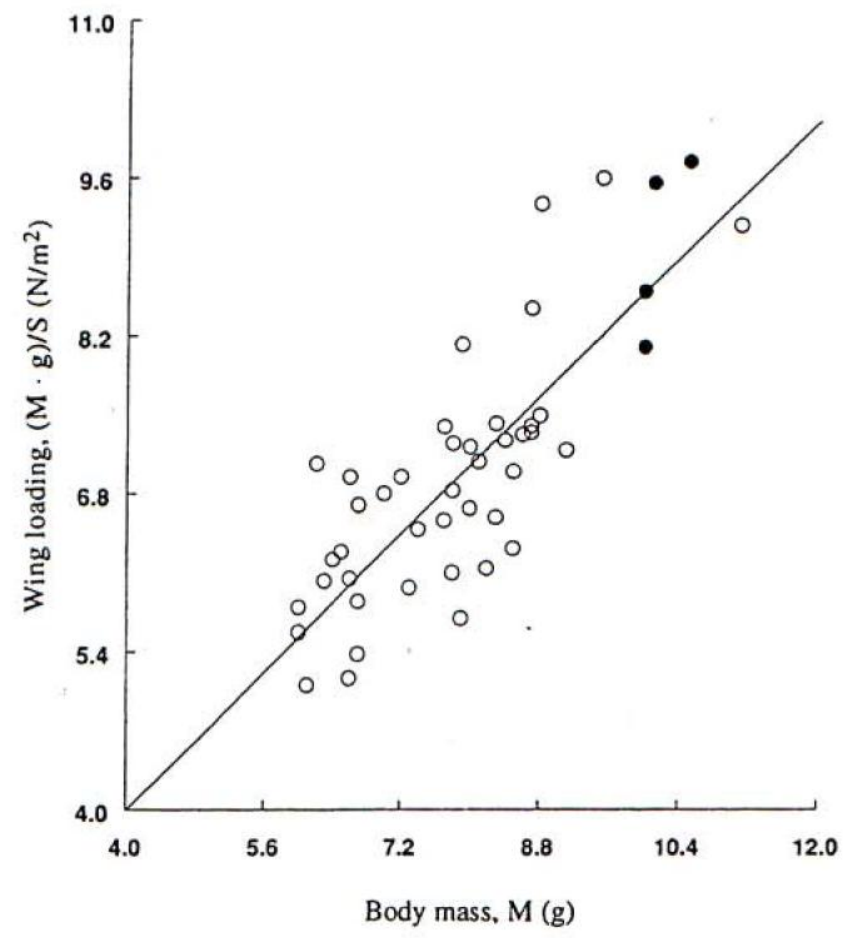

morphology and body mass comparisons between males and females, we used data for 30 males and 107 females.

Insects were sampled on 17 nights during the study period, the majority of which corresponded to light-tagging nights. Of the 2369 insects captured, 1551 were of the size and insect type reported to be consumed by M. lucifugus. Suction and sticky traps caught 1239 and 312 of these insects, respectively. We caught significantly more insects in the cluttered habitat on both suction $\left(\mathrm{t}\left({ }_{16}\right)=2,39, p<0.05\right)$ and sticky traps $\left(\mathrm{t}\left({ }_{16}\right)=3.76, p<0.01\right.$; Fig. 2$)$.

Body mass explains $69 \%$ of the variation in wing loading when all of the individuals are considered $(p<0.001)$ and $59 \%$ when the artificially loaded class is excluded $(p<$ 0.001 ; Fig. 3). Wing area explained only $9 \%$ of the variation in wing loading when all bats are considered $(p<0.05)$ and $11 \%$ when the artificially loaded bats are excluded $(p<$ 0.05; Fig. 4).

Mean rnorphornetric measurements of male and female bats are shown in Table 1. Females had larger masses $\left(\mathrm{F}_{[1.135]} 22.2\right.$, $p<0,001)$ and wing spans $\left(\mathrm{F}_{[1,135]}=6.3, p<0,05\right)$. However, these differences were not present in the light- tagged bats, which did not differ with respect to wingspan, mass, wing loading, or habitat use. Light-tagged females had greater wing areas than males $\left(\mathrm{F}_{[1,45]} 14.8, p<0.001\right)$.

Mean mass, wing loading, and HU values for the 6 classes of bats are given in Table 2. Mass differed between classes $\left(\mathrm{F}_{[5,41]}-6.2, \mathrm{p}<0.001\right)$, the artificially loaded class having a higher mean mass than the male and non-reproductive and postlactating female classes. Mass of the artificially loaded class was not significantly different from that of the pregnant and lactating classes. Wing loading differed between classes
Fig. 4. Relationship between wing area and wing loading when individuals from all classes are included (regression line shown): $y=10.79-0.03 x ; r^{2}=0.10, F_{[1,45]}=4.84$. Excluding the artificially loaded individuals $(\bullet)$, wing area explained $11 \%$ of the variation in wing loading: $y=10.36$; $r^{2}=0.12, F_{[1.42]}=5.44$. Male bats $(+)$ are distinguished from female bats (O).

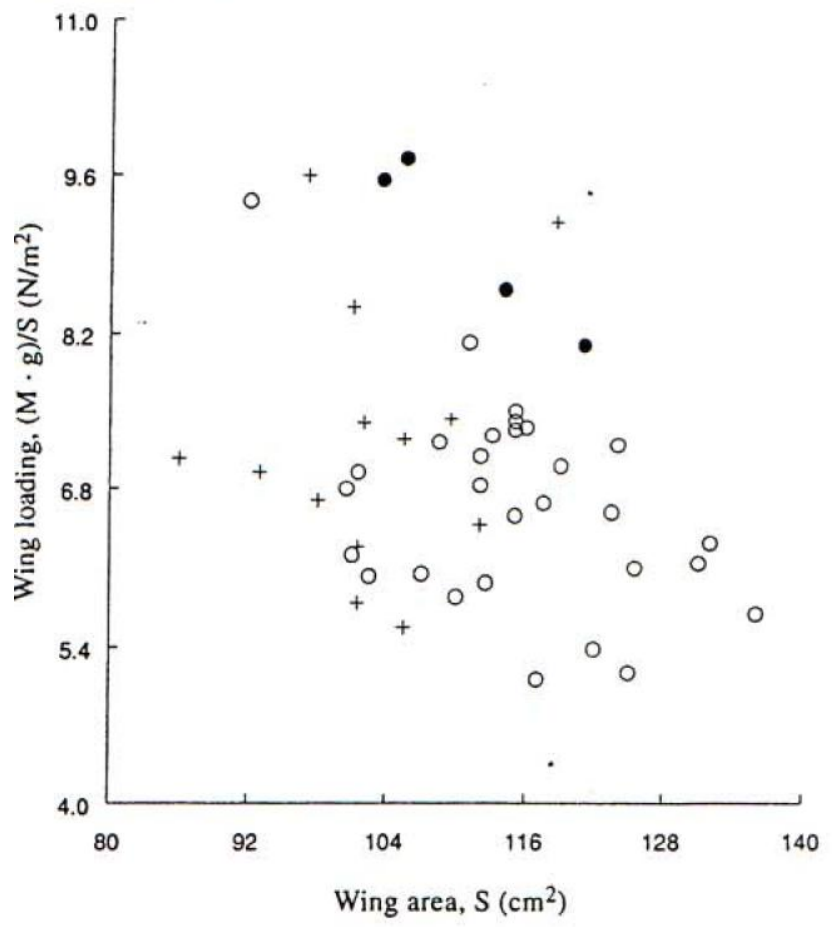

$\left(\mathrm{F}_{[5,41]}=5.9, p<0.001\right)$ the artificially loaded class having higher wing loading than all other classes. Although males had a higher wing loading than non-reproductive females, they did not differ from pregnant, lactating, or postlactating females with respect to wing loading.

With the exception of the artificially loaded class, all sex and reproductive classes concentrated foraging activity in habitat 4 , the most cluttered habitat. Bats also spent considerable time foraging in habitat 3, the edge habitat. All classes spent the least amount of time foraging over water (habitat 2).

There was a significant negative relationship between wing loading and habitat use (Fig. 5). With all light-tagged individuals included in the analysis, wing loading explained $20 \%$ of the variation in habitat use $(p<0.01)$. When the artificially loaded individuals are excluded, wing loading explained $13 \%$ of the variation $(p<0.05)$. The relationship between wing loading and habitat use was not apparent when bats were grouped into their respective classes (Fig. 5) and there were no differences in mean HU values for the 6 classes (Table 2).

\section{Discussion}

Insect sampling showed that the insects known to be consumed by M. lucifugus were more abundant in clutter than in open areas. Thus, a bat foraging in clutter could potentially encounter more prey and have a higher net energy intake than a bat foraging in the open. If morphologically capable of doing so, M. fucifiegus should have spent more time foraging 
Table 1. Morphological measurements and habitat-use indices for male and female bats.

\begin{tabular}{lcccrcc}
\hline & Males & Females & $p$ & $\begin{array}{c}\text { Light-tagged } \\
\text { males }\end{array}$ & $\begin{array}{c}\text { Light-tagged } \\
\text { females }\end{array}$ & $p$ \\
\hline Number & 30 & 107 & & 13 & 34 & \\
Wing span $(\mathrm{cm})$ & $25.86 \pm 0.18$ & $26.62 \pm 0.17$ & $* *$ & $25.74 \pm 0.25$ & $25.79 \pm 0.42$ & $\mathrm{~ns}$ \\
Wing area, $S\left(\mathrm{~cm}^{2}\right)$ & - & - & - & $102.38 \pm 2.31$ & $114.21 \pm 1.68$ & $* * *$ \\
Mass, $M(\mathrm{~g})$ & $7.24 \pm 0.24$ & $8.18 \pm 0.11$ & $* * *$ & $7.58 \pm 0.42$ & $8.09 \pm 0.20$ & $\mathrm{~ns}$ \\
Wing loading, $(M \cdot \mathrm{g}) / \mathrm{S}\left(\mathrm{N} / \mathrm{m}^{2}\right)$ & - & - & - & $7.24 \pm 0.34$ & $6.92 \pm 0.20$ & $\mathrm{~ns}$ \\
Habitat-use index & - & - & - & $3.12 \pm 0.20$ & $3.22 \pm 0.07$ & $\mathrm{~ns}$ \\
\hline
\end{tabular}

NOTE: ${ }^{* *}$, significant at $p<0.01 ; * * *$, significant at $p<0.001 ; \mathrm{ns}$, not significant.

Table 2. Morphological measurements and habitat-use index values for 6 classes of little brown bats.

\begin{tabular}{lcccccc}
\hline & M & NR & P & L & PL & AL \\
\hline Number & 13 & 9 & 6 & 9 & 6 & 4 \\
Mass, $M(\mathrm{~g})$ & $7.58 \pm 0.42 a$ & $7.00 \pm 0.28 a$ & $8.23 \pm 0.34 a b$ & $8.41 \pm 0.18 a$ & $7.72 \pm 0.33 a$ & $10.2 \pm 0.12 b$ \\
Wing loading, $(M \cdot \mathrm{g}) / \mathrm{S}\left(\mathrm{N} / \mathrm{m}^{2}\right)$ & $7.24 \pm 0.34 b$ & $6.00 \pm 0.22 a$ & $6.95 \pm 0.28 a b$ & $6.88 \pm 0.23 a b$ & $6.69 \pm 0.52 a b$ & $9.00 \pm 0.39 c$ \\
Habitat-use index & $3.12 \pm 0.20$ & $3.36 \pm 0.09$ & $3.78 \pm 0.15$ & $3.33 \pm 0.11$ & $3.03 \pm 0.19$ & $2.66 \pm 0.14$ \\
\hline
\end{tabular}

NotE: Within rows, values followed by the same letter are not significantly different (Tukey's test). M, males; NR, non-reproductive females; P, pregnant females; L, lactating females; PL, postlactating females; AL, artifically loaded females.

Fig. 5. Relationship between wing loading and habitat use when all individuals from all classes are included (regression line shown): $y=4.51-0.19 x ; r^{2}=0.20, F_{[1.45]}=11.25$. Excluding the artificially loaded individuals: $y=4.41-$ $0.17 x ; r^{2}=0.13, F_{[1,41]}=6.24$. Male bats $(+)$ and non-reproductive $(\boldsymbol{\square})$, pregnant $(\square)$, lactating $(\mathbf{\Lambda})$, postlactating $(\Delta)$, and artificially loaded female bats $(\bullet)$ are distinguished.

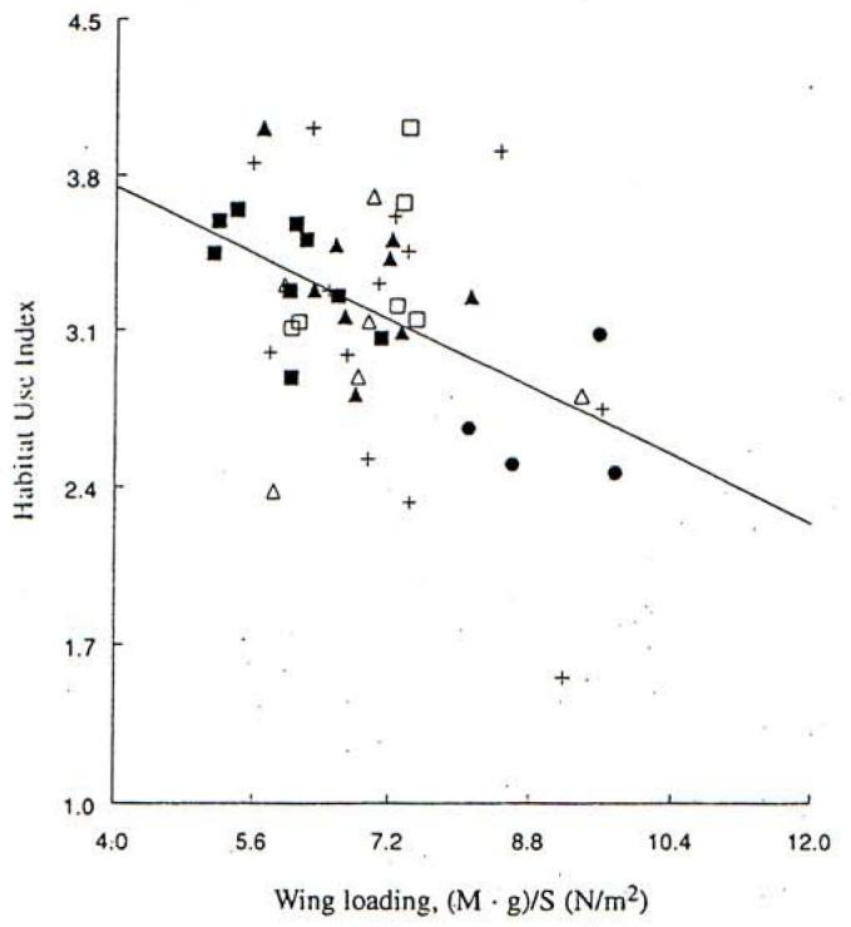

in clutter. This was the case, as male and non-reproductive,. pregnant, lactating, and postlaCtating female classes spent more than $50 \%$ of their time foraging in clutter. The artificially loaded class spent $36 \%$ of foraging time in clutter and
$30.5 \%$ of time in the edge habitat; however, this difference was not significant. All classes spent the least amount of time foraging over water, likely because they only used the creek for drinking and as a reference point for navigation.

The correlation between the number of young born per pregnancy and the degree of dimorphism in the length of the forearm of vespertilionid bats has been interpreted to suggest a selective advantage for larger females in that they are better able to fly with an increased load due to pregnancy (Myers 1978). Female M. lucifugus have a significantly larger head and body and longer forearms than males (Williams and Findley 1979). Similarily, our results show that females have a larger wingspan, forearm, and mass. Probably because of small sample sizes, we detected no morphological differences between light-tagged male and female bats, except that the wing areas of these females were larger. This large wing area is of particular interest because, as with forearms, larger wing areas should permit females to carry heavier loads than males without incurring a decrease in manoeuvrability. This might account for the lack of difference in habitat use between males and females.

The mass increases we found agree with published seasonal changes for M. lucifugus (O'Farrell and Studier 1976). Although our bats were generally heavier than those of O'Farrell and Studier (1976), non-reproductive females in both studies were significantly lighter than pregnant and lactating bats. In our study, postlactating females also had lower mean masses than pregnant and lactating females, whereas no difference was seen by O'Farrell and Studier (1976). This may be due to postlactating females in our study having been caught before prehibernatory fat had been deposited.

Even though wing loading is in part dependant on body mass, the trends seen in the classes with respect to mass were not precisely the same for wing loading, owing to interindividual variation in wing area. Despite this, the fact that $60 \%$ of the variation in wing loading could be explained by body mass suggests that bats with higher wing loading had 
greater mass rather than wings of smaller area. As a result, bats with greater mass should have poorer theoretical flight performance in terms of dealing with clutter. As predicted, there was a significant relationship between wing loading and habitat use. Bats with higher wing loadings tended to forage in areas where the number of objects to detect and avoid was low. Presumably, heavier bats had a higher minimum flightspeed requirement and turning radius, which decreased their manoeuvrability.

Inter-individual variation in mass and wing loading within classes was very high and it is not surprising that there was no difference in habitat use between classes. The classes could not be separated on the basis of wing loading as we had expected. For example, there were pregnant individuals that had a lower wing loading than non-reproductive females. As in pipistrelles, there is a large amount of potential variation in flight performance between individuals at any given time (Webb et al. 1992). As well, there can be large intra-individual variation, which would also affect flight performance. The major source of such variation is likely to be the nightly food intake, which can represent up to $20-30 \%$ of body mass (Kunz 1974). Thus, if a non-reproductive female was caught after it had foraged, it may have a higher body mass than a pregnant bat that has not yet foraged. This potential for large variation, both within and between individuals, highlights the necessity of sampling relatively large numbers of bats.

The relationship between habitat use and wing loading raises some interesting questions about behaviours other than foraging. Our argument for predicting that bats will forage in cluttered habitats assumes that the only selective pressure to forage in cluttered areas is the need to maximize net energy intake. However, other selective pressures no doubt influence where bats choose to forage. For example, predation risk may differ significantly between open and cluttered habitats and therefore individuals may derive not only foraging benefits but also a decreased risk of predation when foraging in cluttered areas. As a result, bats may expend more energy to restrict their feeding to cluttered habitats, despite increased wing loading.

\section{Acknowledgements}

We thank H.D.J.N. Aldridge, E.M. Bayne, R.D. Csada, R.H.M. Espie, A.J.P. Kalcounis, 0.E. Negraeff, and J. Robb for assistance in the field. We acknowledge the staff of Cypress Hills Provincial Park and Fort Walsh National Historic Site for their assistance and thank the University of Regina for use of the field station. The comments of H.D.J.N Aldridge, R.M.R. Barclay, 1.R. Speakman, G.C. Sutter, and two anonymous reviewers greatly improved earlier versions of the manuscript. This study was funded by a Natural Sciences and Engineering Research Council of Canada (NSERC) operating grant and University of Regina President's NSERC grant to R.M.B. and a Sigma Xi Grant-in-Aid of Research to M.C.K.

\section{References}

Aldridge, H.D.J.N. 1986a. Manoeuvrability and ecological segregation in the little brown (Myotis luctfugus) and Yuma (M. yumanensis) bats (Chiroptera: Vespertilionidae). Can. J. Zool. 64: 1878-1882.
Aldridge, H. D.1 .N. 1986b. Manoeuvrability and ecolog in British bats. Myotis, 23-24: 57-60.

Aldridge, H.D.J.N. 1987. Turning flight of bats. J. Exi Biol. 128: 419-425.

Aldridge, H.D.J.N., and Brigham, R.M. 1988. Load carrying and maneuverability in an insectivorous bat: test of the 5\% "rule" of radiotelemetry. J. Mammal 69: 379-382.

Aldridge, H.D.I.N., and Rautenbach, I.L. 1987. Morphology, echolocation and resource partitioning i insectivorous bats. J. Anim. Ecol. 56: 763-778.

Anthony, E.L.P., and Kunz, T.H. 1977. Feeding strategies of the little brown bat, Myoris lucifiigus, in southern New Hampshire. Ecology, 58: 775-786.

Barclay, R.M.R., and Bell, G.P. 1988. Marking and observational techniques. In Ecological and behaviors methods for the study of bats. Edited by T.H. Kunz, Smithsonian Institution Press, Washington, D.C. pp. 59-75.

Belwood, J.J., and Fenton, M.B. 1976. Variation in the diet of Myotis tucifugus (Chiroptera: Vespertilionidae Can. J. Zool. 54: 1674-1678.

Brigham, R.M., Aldridge, H.D.J.N., and Mackey, R.L. 1992. Variation in habitat use and prey selection by Yuma bats Myotis yumanensis. J. Mammal. 73: 640645.

Buehler, E.R. 1976a. Prey selection by Myotis lucifugus (Chiroptera: Vespertilionidae). Am. Nat. 110: 619-62

Buehler, E.R. 1976b. A chemiluminescent tag for tracking bats and other small nocturnal animals. J. Mammal. 57. 173-176.

Buehler, E.R. 1980. The development of flight, foraging and echolocation in the little brown bat (Myotis lucifugus). Behav. Ecol. Sociobiol. 6: 211 -218.

Crome, F.H.J., and Richards, G.C. 1988. Bats and gap! microchiropteran community structure in a Queenslarn rain forest. Ecology, 69: 1960-1969.

Fenton, M.B. 1988. Detecting, recording and analyzing vocalizations of bats. In Ecological and behavioral methods for the study of bats. Edited by T.H. Kunz. Smithsonian Institution Press, Washington, D.C. pp. 91-104.

Fenton, MB., and Barclay, R.M.R. 1980. Myotis lucifugus. Mammalian Species Account No. 142. The American Society of Mammalogists. pp. 1 -8.

Grant, P.R. 1986. Ecology and evolution of Darwin's finches. Princeton University Press, Princeton, N.J.

Griffin, D.R., Friend, J., and Webster. F. 1965. Target discrimination by the echolocation of bats. J. Exp. Zool. 158: 155-168.

Hughes, P.M., and Rayner, J.M.V. 1993. The flight of pipistrelle bats Pipistrellus pipistrellu.s-during pregnancy and lactation. J. Zool. (Lond.), 230: $541-555$.

Kalcounis, M.C., Csada, R.D., and Brigham, R.M. 1992. Axle grease as an alternative adhesive for use o sticky traps. Can_Entomol. 124: 561-562.

Kunz, T.H. 1974. Reproduction, growth and mortality oi the vespertilionid bat, Eptesicus fuscus, in Kansas. J. Mammal. 55: 1-13. 
Kunz, T.H. 1988. Methods of assessing the availability of prey to insectivorous bats. In Ecological and behavioral methods for the study of bats. Edited by T.H. Kunz. Smithsonian Institution Press, Washington, D.C. pp. 191-209.

Kurta, A., and Kunz, T.H. 1987. Size of bats at birth and maternal investment during pregnancy. Symp. Zool. Soc. Lond. 57: 79-106.

Losos, J.B. 1990. Ecomorphology, performance capability, and scaling of West Indian Anolis lizards: an evolutionary analysis. Ecol. Monogr. 60: 369-388.

McKenzie, N.L., and Rolfe, J.K. 1986. Structure of bat guilds in the Kimberley mangroves Australia. J. Anim. Ecol. 55: 401-420.

Myers, P. 1978. Sexual dimorphism in size of vespertilionid bats. Am. Nat. 112: 701-712.

Norberg, U.M. 1981. Flight morphology and the ecological niche. Symp. Zool. Soc. Lond. 48:

173-197.

Norberg, U.M., and Rayner, J.M.V. 1987. Ecological morphology and flight in bats (Mammalia; Chiroptera): wing adaptations, flight performance, foraging strategy and echolocation. Philos. Trans. R. Soc. Lond. B Biol. Sci. 316: 335-427.

O'Farrel, M.J., and Studier, E.H. 1976. Seasonal changes in wing loading, body composition, and organ weights in Myotis thysanodes and M. lucifugus (Chiroptera: Vespertilionidae). Bull. South. Calif. Acad. Sci. 75: 258-266.
Pennycuick, C.J. 1975. Mechanics of flight. In Avian biology. Edited by D. Earner and J.R. King, Academic Press, London. pp. 1-75.

Racey, P.A. 1974. Ageing and assessment of reproductive status of pipistrelle bats, Pipistrellus pipistrellus. J. Zool. (1965-1984), 173: 264-271.

Saunders, M.B., and Barclay, R.M. 1992. Ecomorphology of insectivorous bats: a test of predictions using two morphologically similar species. Ecology, 73: 1335-1345.

Speakman, JR., and Racey, P.A. 1987. The energetics of pregnancy and lactation in brown long-eared bats (Plecotus auritus). In Recent advances in the study of bats. Edited by M.B. Fenton, P.A. Racey, and J.M.V. Rayner. Cambridge University Press, Cambridge. pp. 367-395.

van Zyll de Jong, C.G. 1985. Handbook of Canadian mammals. H. Bats. National Museums of Canada, Ottawa, Ont., Canada.

Webb, P.I., Speakman, JR., and Racey, P.A. 1992. Inter- and intra-individual variation in wingloading and body mass in female pipistrelle bats: theoretical implications for flight performance. J. Zool. (Lond.), 228: 669-673.

Williams, D.F., and Findley, J.S. 1979. Sexual size dimorphism in vespertilionid bats. Am. Midl. Nat. 102: 113-126.

Zar, J.H. 1984. Biostatistical analysis. Prentice-Hall, Englewood Cliffs, N.J. 